\title{
Stereoselective annelation of 3-substituted imidazo[4,5-b]pyridines with cyanoacetylenic alcohols and domino rearrangement of the adducts
}

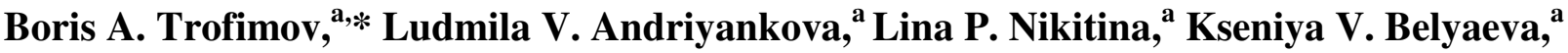 \\ Anastasiya G. Mal'kina, ${ }^{a}$ Oleg A. Dyachenko, ${ }^{\text {b }}$ Olga N. Kazheva, ${ }^{\text {b }}$ Anatolii N. Chekhlov, \\ and Andrei V. Afonin ${ }^{\mathrm{a}}$ \\ ${ }^{a}$ A.E. Favorsky Irkutsk Institute of Chemistry, Siberian Branch, Russian Academy of Sciences, \\ 1 Favorsky Str., Irkutsk 664033, Russian Federation \\ ${ }^{b}$ Institute of Problems of Chemical Physics, Russian Academy of Sciences, 1 Academician N.N. \\ Semenov Str., Chernogolovka 142432, Russian Federation \\ E-mail: boris_trofimov@irioch.irk.ru
}

\begin{abstract}
Imidazo[4,5- $b$ ]pyridines are readily annelated $\left(45-50{ }^{\circ} \mathrm{C}, 24-30 \mathrm{~h}, \mathrm{MeCN}\right)$ with cyanoacetylenic tertiary $\alpha$-alcohols to give stereoselectively functionalized 1,3-oxazolo[3,2- $a$ ]imidazo[4,5$b$ ]pyridines in 50-88\% yields. The adducts undergo a facile stereoselective hydrolytic domino rearrangement to functionalized derivatives of 2,3-diaminopyridines.
\end{abstract}

Keywords: Annelation, formamides, imidazopyridines, rearrangement, zwitterions

\section{Introduction}

Derivatives of imidazole and pyridine are of special interest in drug design. ${ }^{1,2}$ The condensed heterocyclic systems consisting of imidazole and pyridine rings (imidazopyridines) often possess pharmaceutically valuable properties which are not typical for either of the separate moieties. For example, a popular soporific remedy, "Zolpidem" ("Ivadal"), is a functionalized imidazo[1,2a]pyridine. ${ }^{2}$ Among other derivatives of imidazopyridines, are potent nitric-oxide synthase inhibitors of inflammatory diseases, ${ }^{3}$ inhibitors of AKT kinase, ${ }^{4}$ preventive and/or therapeutic agents for neutrophilic inflammation disease, ${ }^{5}$ compounds with tuberculostatic ${ }^{6}$ and hypoglycemic ${ }^{7}$ activities, angiotensin II receptor antagonists, ${ }^{8}$ and anticoccidial agents. ${ }^{9}$ A series of imidazo[1,2-a]pyridines bearing sulfonylurea functions exhibit herbicidal activity. ${ }^{10}$

Most reported syntheses of imidazopyridines are, as a rule, laborious and multi-step (up to 6 steps). Therefore, the search for novel straightforward approaches to the synthesis of functionalized imidazopyridines remains a challenge. 
The objective of this present work was to develop a straightforward efficient approach to the synthesis of new condensed functionalized heterocyclic systems combining and imidazo[4,5$b$ ]pyridine skeleton and a 1,3-oxazole moiety. For this, we have studied the reaction of substituted imidazo[4,5- $b$ ]pyridines with readily available cyanoacetylenic tertiary $\alpha$-alcohols. ${ }^{11}$

From out recent findings related to the annelation of the cyanoacetylenic alcohols with pyridines, ${ }^{11 b, 12}$ quinoline and quinoxaline, ${ }^{13}$ phenanthridines, ${ }^{14}$ natural alkaloids ${ }^{15}$ and substituted

benzimidazoles ${ }^{16}$ one might expect that either the pyridine or the imidazole (or both) components of an imidazo[4,5- $b$ ]pyridine would be involved in the reaction to furnish novel 1,3oxazoloimidazopyridine tricyclic fused scaffolds. Therefore, a fundamental part of the objective is also the issue of competition between the imidazole and pyridine nitrogen atoms as nucleophiles towards the electron-deficient acetylenic bond.

\section{Results and Discussion}

The experimental results have shown that 3-substituted imidazo[4,5- $b]$ pyridines 1a,b are readily annelated with cyanoacetylenic tertiary $\alpha$-alcohols $\mathbf{2 a}, \mathbf{b}\left(45-50{ }^{\circ} \mathrm{C}, 24-30 \mathrm{~h}, \mathrm{MeCN}, \mathbf{1 : 2}\right.$ molar ratio equals $1: 1$ ) to give (Z)-3-cyanomethylene-1,3-oxazolo[3,2- $a$ ]imidazo[4,5-b]pyridines 3a-d in $50-88 \%$ yields (Table 1). No E-isomers of the adducts 3a-d have been discernible in the reaction mixture, i.e. the annelation is strictly stereoselective. Neither alternative adducts $\mathbf{4}$ nor possible diadducts with participation of both imidazole and pyridine counterparts have been detected among the reaction products thus indicating that imidazole nitrogen atom $N(1)$ entirely wins the competition against the pyridine nitrogen $N(4)$ in the nucelophilic addition to the triple bond. In other words, the annelation is also strongly regioselective. Notably, although under the same conditions the annelation of 1-benzylimidazo[4,5-b]pyridine 1c with cyanoacetylenic alcohol 2a proceeds reluctantly to afford the corresponding adduct 1,3-oxazoloimidazopyridine 3e (also of $Z$-configuration only) just in $18 \%$ yield, no alternative adducts are formed (Table 1).

When carried out at room temperature $\left(20-25^{\circ} \mathrm{C}\right)$, completion of the annelation takes a much longer time (up to $147 \mathrm{~h}$ ), though the yields of the adducts 3a-e increase by approximately $10 \%$ (relative to the yields shown in Table 1), obviously due to the milder reaction conditions.

The pyridine nitrogen atom was not involved into the annelation even when adduct $\mathbf{3 c}$ was allowed to react with cyanoacetylenic alcohol $\mathbf{2 b}\left(20-25{ }^{\circ} \mathrm{C}, 147 \mathrm{~h}\right)$. Also, no bis-adduct was isolated even when the reactants $\mathbf{1 a}$ and $\mathbf{2 b}$ were taken in the 1:2 molar ratio.

The structure of adducts 3a-e was established by NMR $\left({ }^{1} \mathrm{H},{ }^{13} \mathrm{C}, 2 \mathrm{D}\right)$ and IR spectroscopy. Thus, in the ${ }^{1} \mathrm{H}$ NMR spectra of 1,3-oxazoloimidazopyridines 3a-e, olefinic protons (H-10, the $=\mathrm{CHCN}$ fragment) appear as singlets in the region $4.43-4.55 \mathrm{ppm}$ thus indicating to the formation of only one isomer (NOESY). In the IR spectra, the absorption bands of the cyano groups on the double bond are observed at $2202-2213 \mathrm{~cm}^{-1}$. 
Table 1. Formation of 1,3-oxazoloimidazopyridines 3a-e from substituted imidazo[4,5$b$ ]pyridines 1a-c and cyanoacetylenic alcohols $\mathbf{2 a}, \mathbf{b}$
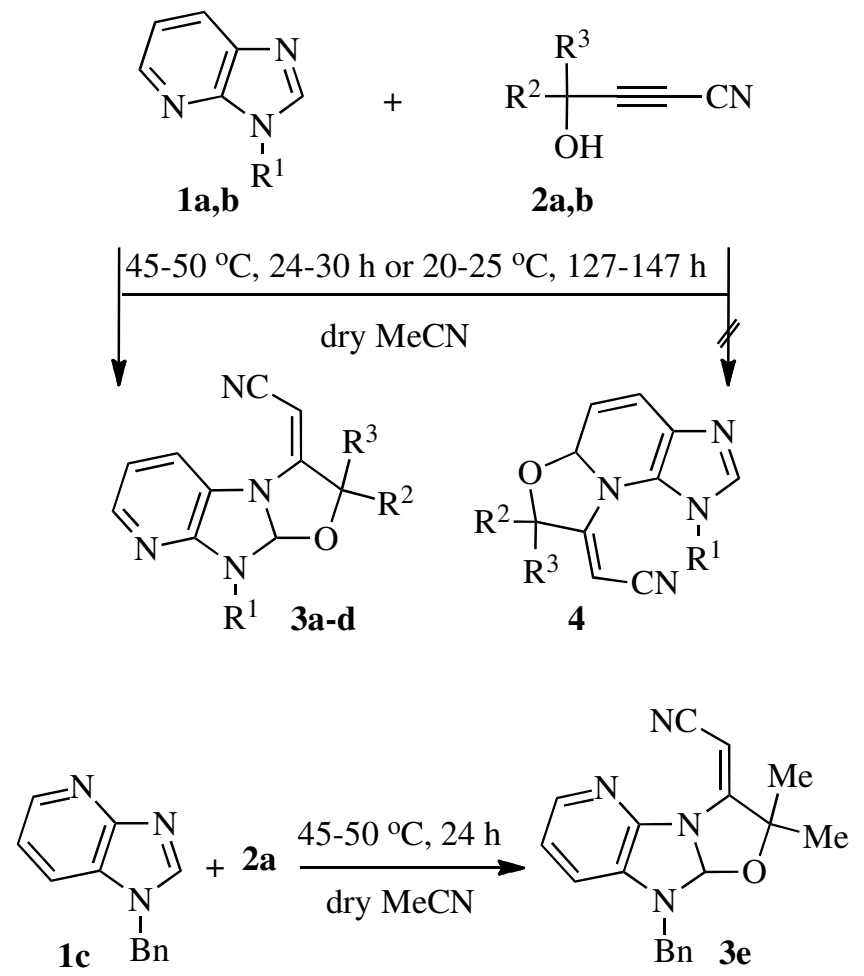

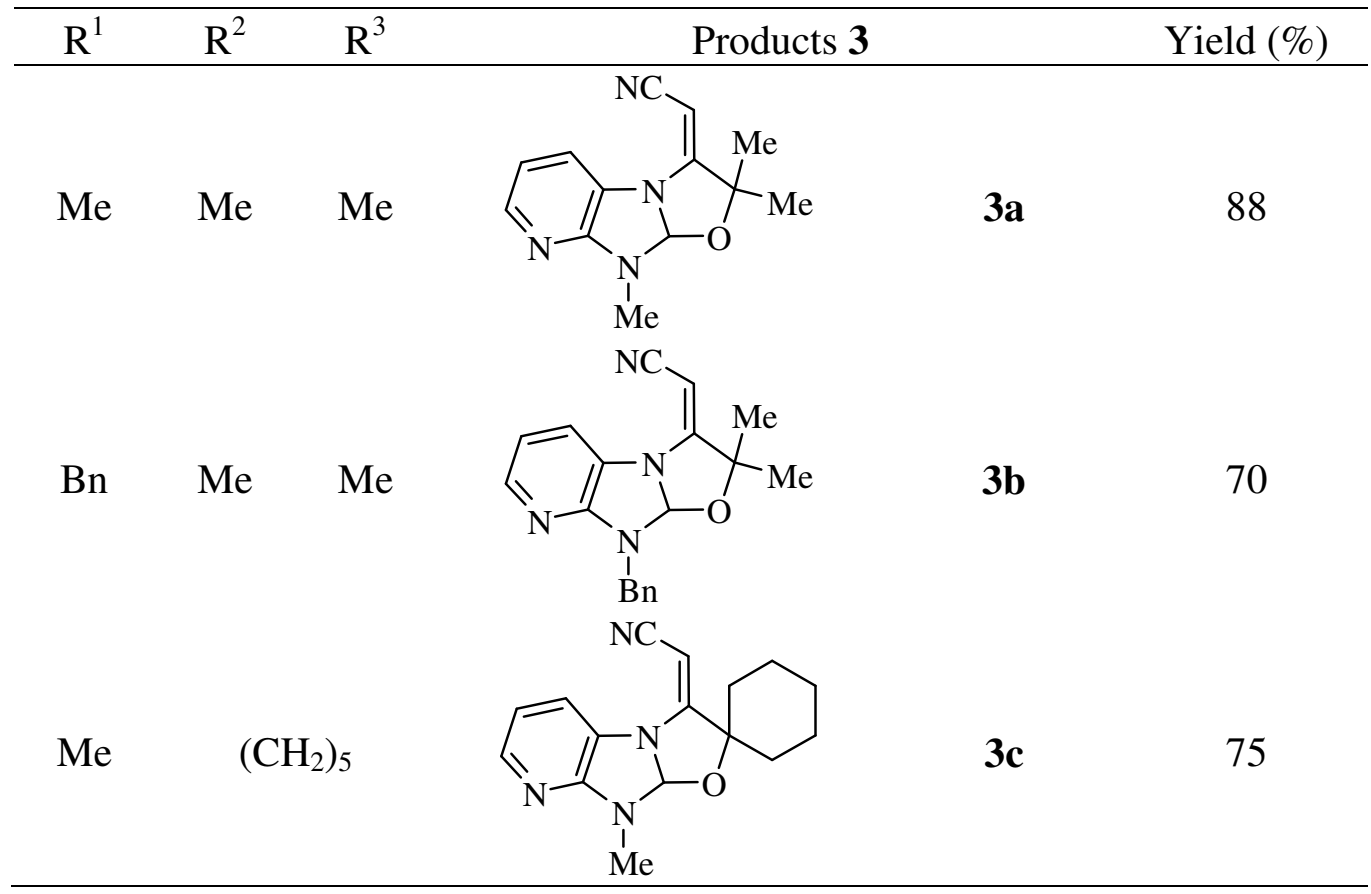


Table 1. Continued

\begin{tabular}{|c|c|c|c|c|c|}
\hline $\mathrm{R} 1$ & $\mathrm{R} 2$ & R3 & Products 3 & & Yield (\%) \\
\hline $\mathrm{Bn}$ & & & & $3 d$ & 50 \\
\hline $\mathrm{Bn}$ & $\mathrm{M}$ & $\mathrm{Me}$ & & $3 \mathbf{e}$ & 18 \\
\hline
\end{tabular}

According to the NOESY spectra, the 1,3-oxazoloimidazopyridines 3a-e are Z-isomers: the cross-peaks between olefinic proton $\mathrm{H}-10$ and the immediately adjacent protons of cyclohexyl (for 3c) or Me group (for 3e) are observed (Figure 1).
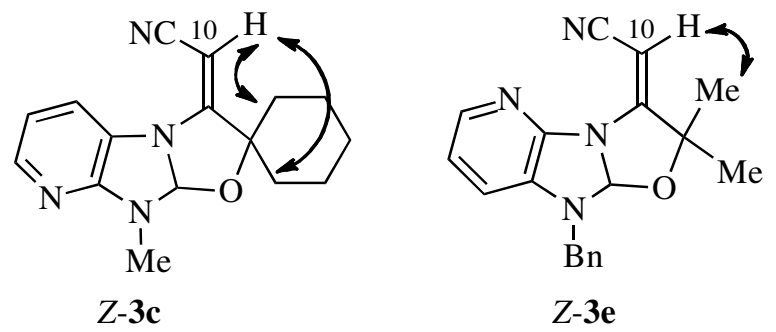

Figure 1. Cross-peaks in the 2D NOESY spectra of 1,3-oxazoloimidazopyridines $\mathbf{3} \mathbf{c}$ and $\mathbf{3 e}$.

Apparently, the annelation is triggered by the addition of imidazopyridines 1a,b via their imidazole nitrogen atom $N(1)$ as neutral nucleophiles to cyanoacetylenic alcohols 2a,b to generate zwitterions A having a vinyl carbanion moiety which is then converted into the oxygencentered zwitterions $\mathbf{B}$ the proton transfer (in either an intra- or intermolecular manner) from the hydroxyl group to the carbanionic center. The secondary zwitterions $\mathbf{B}$ undergo the ring closure at the $C(2)$ position of the imidazole ring to form the final annelated adducts 3a-d (Scheme 1). 

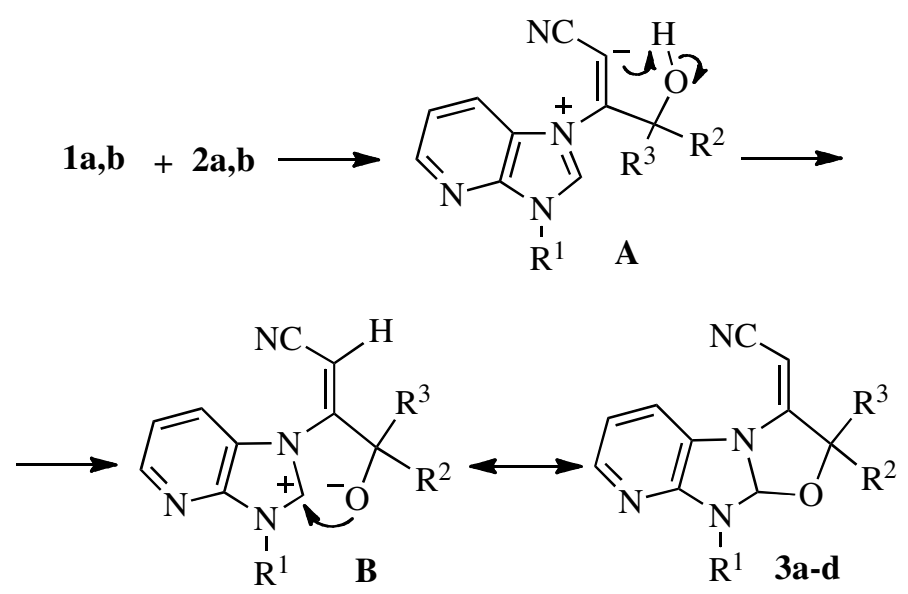

Scheme 1. Proposed mechanism of formation 1,3-oxazoloimidazopyridines 3a-d.

The Z-configuration of the final adducts 3a-d is the expected result of the nucleophilic addition to acetylenes, which is known to proceed in a concerted trans-fashion. ${ }^{17}$ Notably, the 1,3-oxazoloimidazopyridines 3a-d retain a contribution of zwitterionic form $\mathbf{B}$ (an inner salt). A similar consideration is true also for the formation of adduct $3 \mathbf{e}$.

The regioselectivity of the annelation likely results from the steric constrains between the cyanomethylene group and the substituents $\mathrm{R}^{1}$ at the imidazole $N(3)$ atom in the possible alternative adducts 4 (cf. Table 1). Indeed, the nucleophilicities of $N(1)$ of the imidazole ring and $N(4)$ of the pyridine ring should not differ significantly since the basicities of pyridine and benzimidazole, an analog of the imidazopyridines 1a,b, are close $\left(\mathrm{p} K_{\mathrm{a}}=5.20\right.$ and 5.50 for pyridine and benzimidazole, respectively ${ }^{1}$ ). This conclusion is in agreement with the low yield $(18 \%)$ of adduct $\mathbf{3 e}$, in which the cyanomethylene group faces the steric repulsion from the lone electron pair of the $N(4)$ pyridine atom.

1,3-Oxazoloimidazopyridines 3a-d, when passed through a column packed with neutral alumina, or in moist ethanol, undergo the hydrolytic domino rearrangement to functionalized derivatives of 2,3-diaminopyridines conjugated with a 2-aminodihydrofuran moiety - $(E)-N$-(3\{[5-amino-2,2-dialkyl-3(2H)-furanyliden]amino $\}$-2-pyridinyl)- $N$-alkylformamides 5a-d in 83 98\% yields (Table 2). This exceptionally facile multi-step rearrangement is rigorously stereoselective: the products 5a-d are formed exclusively in the $E$-configuration (relative to the $\mathrm{C}=\mathrm{N}$ bond). Likewise, 1,3-oxazoloimidazopyridine 3e rearranges to a similar derivative of 2,3diaminopyridine of $E$-configuration in $46 \%$ yield (Table 2). 
Table 2. Rearrangement of 1,3-oxazoloimidazopyridines 3a-e to pyridinyl- $N$-substituted formamides 5a-e

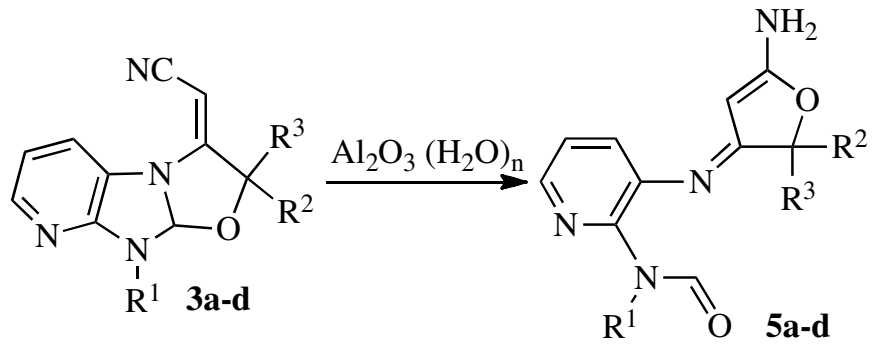

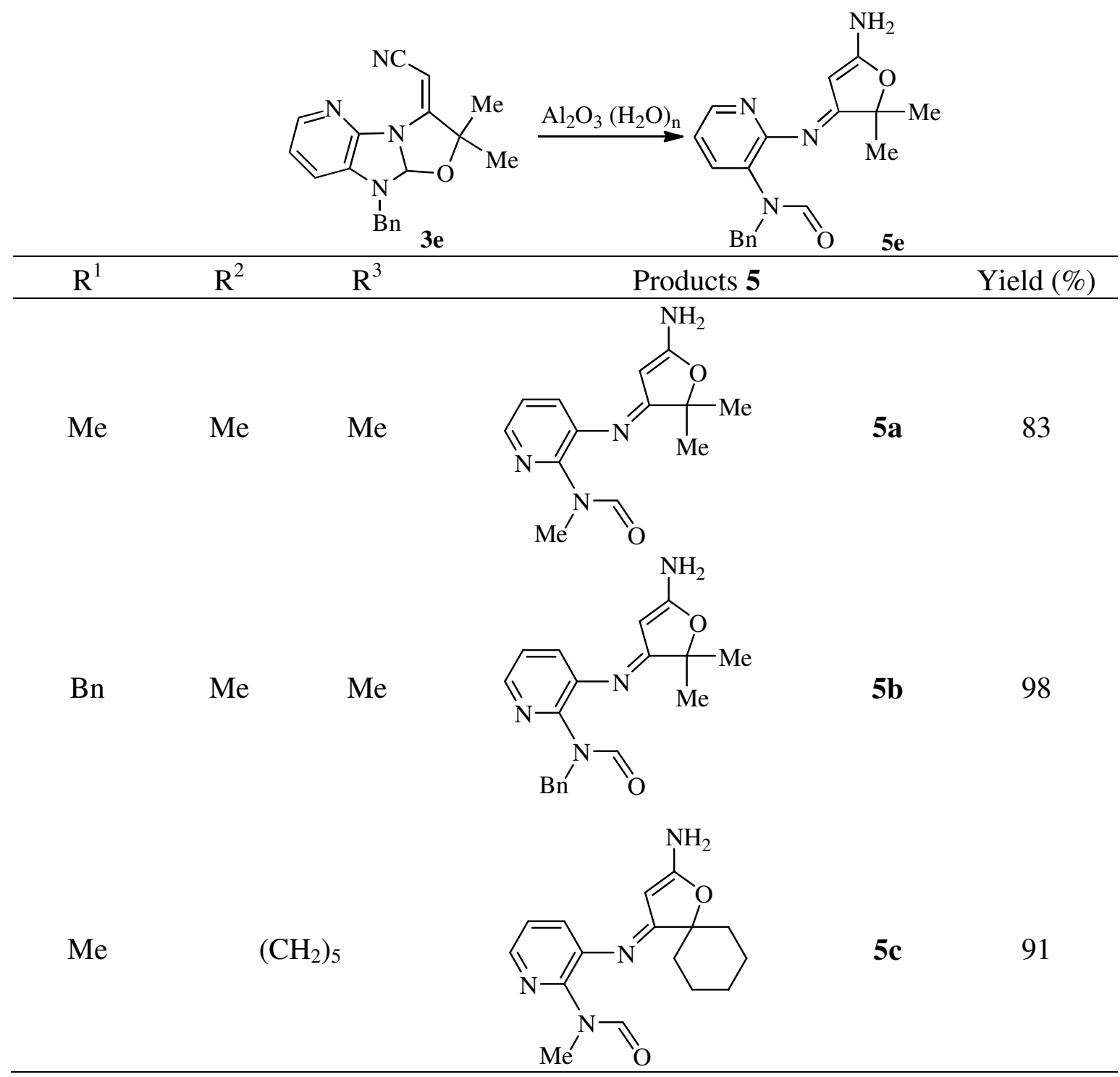


Table 2. Continued

\begin{tabular}{lllll}
\hline $\mathrm{R} 1$ & $\mathrm{R} 2$ & $\mathrm{R} 3$ & Yield (\%) \\
$\mathrm{Bn}$ & $\mathrm{Me}$ & $\mathrm{Me}$ & $\mathbf{5 d}$ & \\
\hline
\end{tabular}

(E)-Pyridinyl- $N$-substituted formamides 5a-e were isolated as crystals. Their structures are based on analogy with that of formamide 5c, which was established by X-ray diffraction analysis, and confirmed using ${ }^{1} \mathrm{H}$ and ${ }^{13} \mathrm{C}$ NMR, UV and IR techniques.

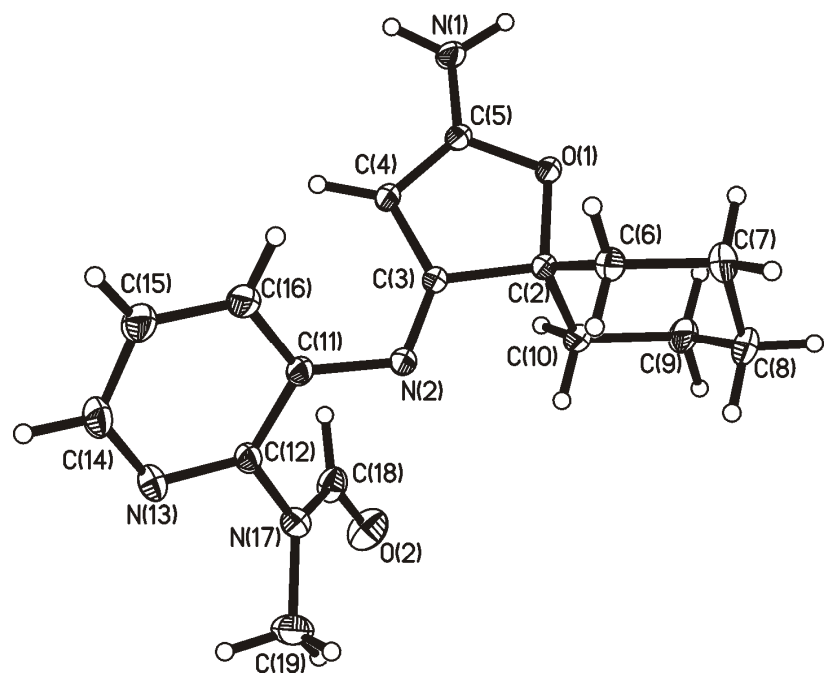

Figure 2. Molecular structure of (E)-pyridinyl- $N$-methylformamide 5c.

Crystal structure of formamide $\mathbf{5 c}$ is formed by one crystallographically independent molecule (Figure 2) taking a general position. The cyclohexane ring has a chair conformation. The furan and pyridine heterocycles are almost planar, maximum deviation of atoms from their average planes do not exceed $0.02 \AA(C(2)$ and $C(12)$ atoms). The dihedral angle between these planes is $125.4^{\circ}$. Deviations of the $N(1)$ and $N(2)$ atoms from plane of the furan cycle are 
insignificant ( 0.01 and $0.03 \AA$, respectively). The $N(2)$ and $N(17)$ atoms deviate from the plane of the pyridine ring by 0.23 and $0.10 \AA$. The fragment formed by the $O(2) C(18) N(17) C(19)$ atoms is practically planar, maximum deviation of atoms from its average plane being $0.02 \AA$ $(C(18)$ atom). This plane forms with planes of the furan and pyridine moieties the dihedral angles of 117.4 and $130.5^{\circ}$, respectively.

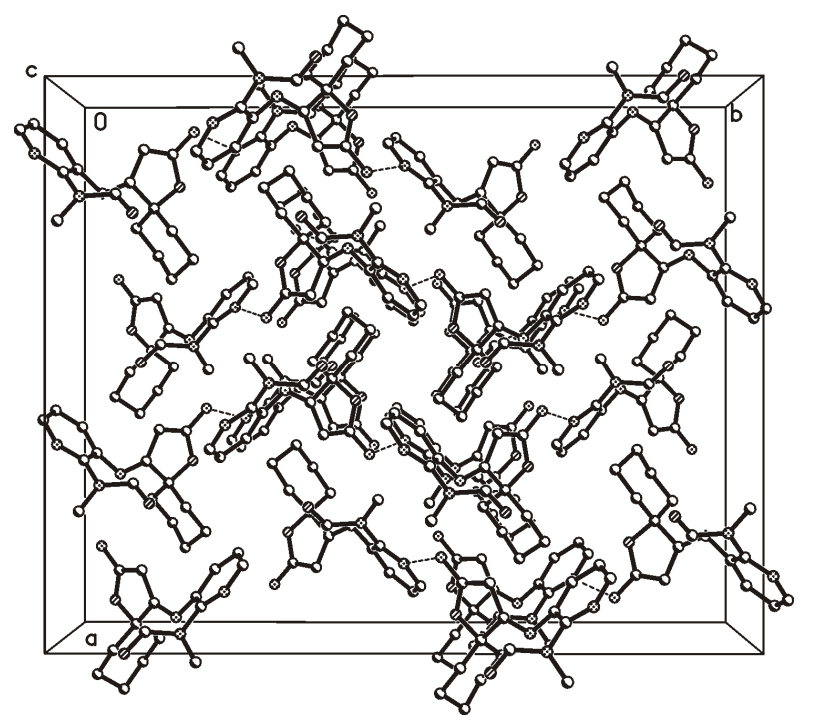

Figure 3. Crystal structure of formamide $\mathbf{5 c}$.

Crystal structure of formamide $\mathbf{5 c}$ is given in Figure 3. In this compound, the molecules are bonded in chains (shorten distances along the axis $b$ ) via hydrogen bonding $N-\mathrm{H} \ldots N: N(1) \ldots N(2)$ - 3.026(2) $\AA, N(1)-\mathrm{H}(1 \mathrm{~A})-0.93(2) \AA, \mathrm{N}(2) \ldots \mathrm{H}(1 \mathrm{~A})-2.14(2) \AA, N(1)-\mathrm{H}(1 \mathrm{~A}) \ldots N(2)-159(2)^{\circ}$, $N\left(1^{\prime}\right) \ldots N(13)-2.999(2) \AA, N\left(1^{\prime}\right)-\mathrm{H}\left(1 \mathrm{~B}^{\prime}\right)-0.95(3) \AA, N(13) \ldots \mathrm{H}\left(1 \mathrm{~B}^{\prime}\right)-2.09(3) \AA, N\left(1^{\prime}\right)-$ $\mathrm{H}\left(1 \mathrm{~B}^{\prime}\right) \ldots N(13)-160(2)^{\circ}$ (sum of van-der-Waals radii $N \ldots \mathrm{H}-2.75 \AA, N \ldots N$ is $3.10 \AA^{18}$ ).

Obviously, the rearrangement of 1,3-oxazoloimidazopyridines 3a-d starts with the cleavage of polar $\mathrm{C}(2)-\mathrm{O}$ bond by water to deliver the intermediates $\mathbf{C}$ (Scheme 2 ) which further rearrange to the intermediates D having a formamide function, probably stabilized by intramolecular $\mathrm{H}$ bonding between the $\mathrm{NH}$ moiety and the carbonyl oxygen. The latter, being an $\mathrm{NH}$ vinylamine, undergoes a 1,3-hydrogen shift to produce the imine intermediates $\mathbf{E}$, in which the free rotation of the $\mathrm{CN}$ function is allowed. By virtue of this, the ring closure by addition of hydroxyl function to the $\mathrm{CN}$ bond to furnish the iminodihydrofuran intermediates $\mathbf{F}$ becomes possible. The 1,3hydrogen shift in the intermediates $\mathbf{F}$ to form iminodihydrofuranylidene moiety in final products 5a-d completes the domino sequence.

The rearrangement of $\mathbf{3 e}$ to $\mathbf{5 e}$ would pass through similar steps. 

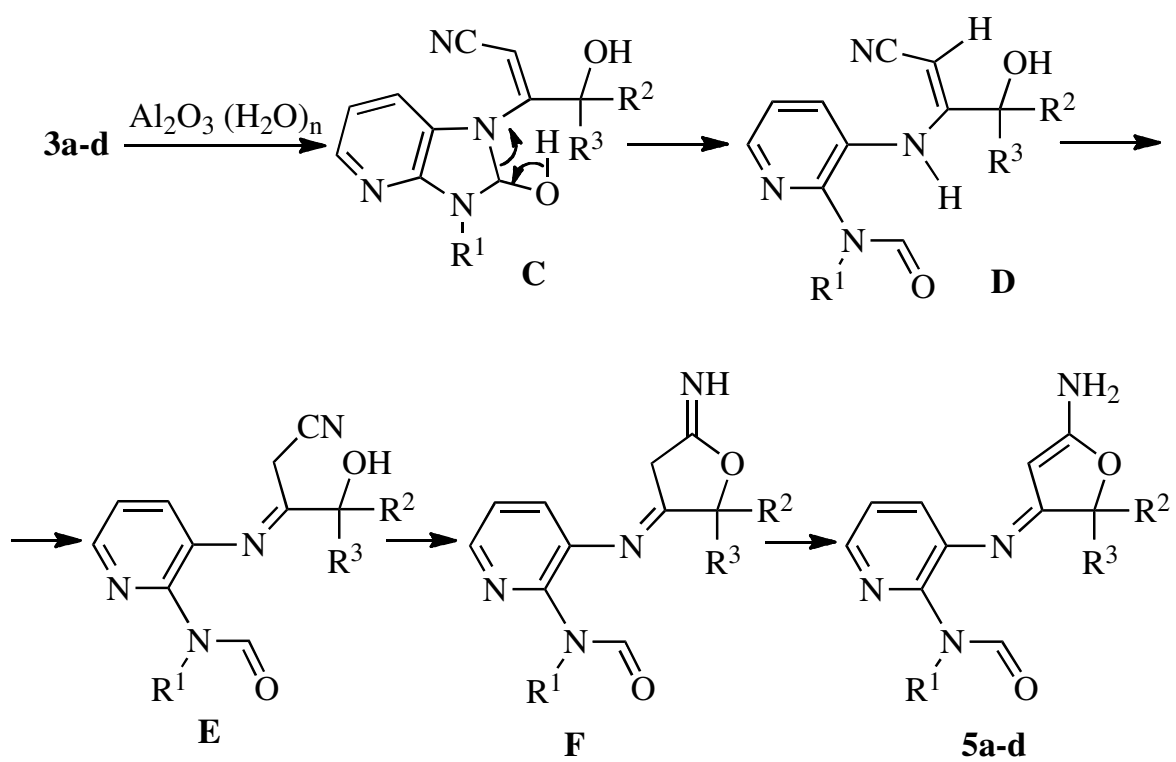

Scheme 2. Probable steps of the rearrangement of (Z)-1,3-oxazoloimidazopyridines 3a-d to (E)-pyridinyl- $N$-alkylformamides 5a-d.

The driving force of this multi-step rearrangement is plausibly the formation of a long-range through-conjugated system of the push-pull type, accomplished in the final products 5a-d. Despite the distorted coplanarity of the pyridine and furan rings in the crystal state (the corresponding dihedral angle is $125.4^{\circ}$, Figure 2), the conjugation can still be partly realized, particularly in solution, or in excited or transition states (during certain reactions).

Easrlier, a simlar deep rearrangement was observed for the adducts of benzimidazoles with cyanoacetylenic tertiary $\alpha$-alcohols. ${ }^{16 a}$

The rearrangement products 5a-e can be prepared directly from reactants $\mathbf{1}$ and $\mathbf{2}$ avoiding the isolation of annelated species 3a-e by passing the reaction mixture through a layer of alumina.

An attempt to obtain a monocrystal of 1,3-oxazoloimidazopyridine $3 c$ [where $R^{1}=M e, R^{2}-R^{3}$ $=\left(\mathrm{CH}_{2}\right)_{5}$ ] from moist ethanol ends up with the formation of crystalline rearrangement product 5 c.

In the ${ }^{1} \mathrm{H}$ NMR spectra of $(E)$-pyridinyl- $N$-substituted formamides $\mathbf{5 a - e}$, the proton of the formamide fragment (H-14) is observed in the region 8.23-8.78 ppm. In the ${ }^{13} \mathrm{C}$ NMR spectra, carbonyl carbon resonates at 163.2-169.8 ppm. In the IR spectra, the absorption bands of the $\mathrm{C}=\mathrm{O}$ group are present at $1659-1684 \mathrm{~cm}^{-1}$.

The direct synthesis of the rearrangement products 5a-e was monitored as an example of a three-component reaction, between imidazopyridine 1a, cyanoacetylenic tertiary $\alpha$-alcohol $\mathbf{2 a}$ and water (1:1:1 molar ratio) in $\mathrm{CD}_{3} \mathrm{CN}$ solution (room temperature, NMR tube). The reaction was followed by the methyl and olefin proton signals in the ${ }^{1} \mathrm{H}$ NMR spectra (Scheme 3 ). 


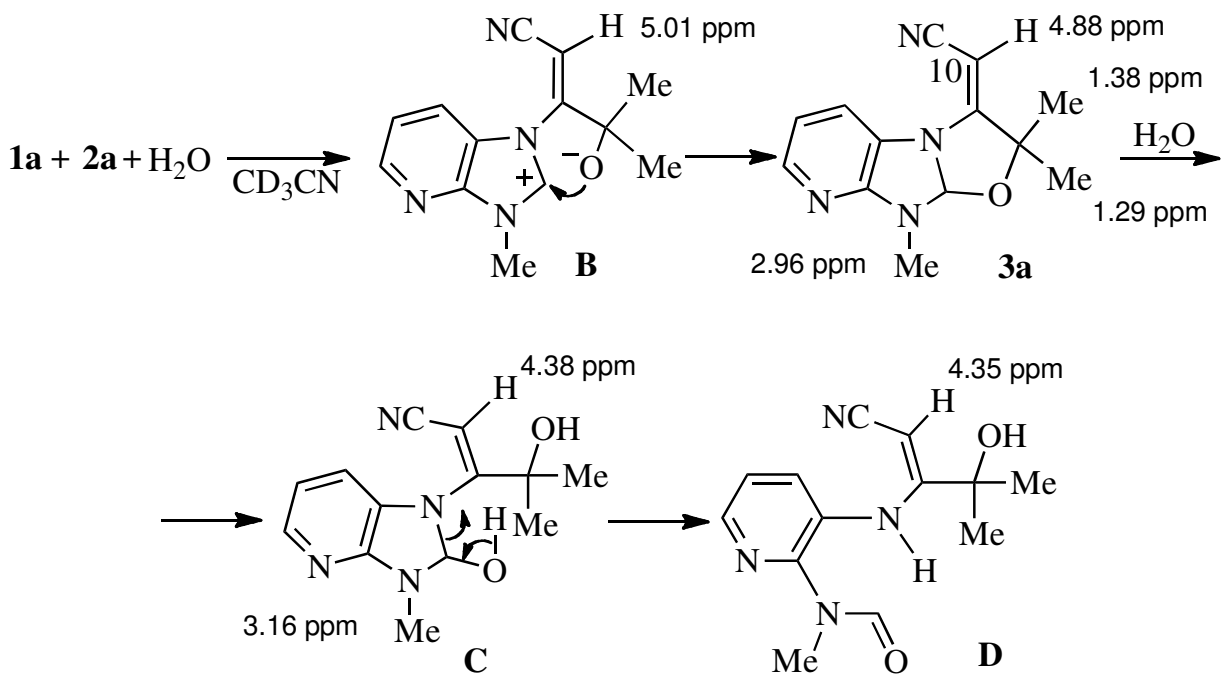

Scheme 3. Monitoring of the three-component reaction of imidazopyridine 1a with cyanoacetylenic alcohol 2a and water.

After $1 \mathrm{~h}$, in the spectrum, along with the signals of starting materials [1.48 (Me in cyanoacetylenic $\alpha$-alcohol 2a) and 3.83 ( $N$-Me in imidazopyridine 1a) ppm], weak singlets at 2.96, 4.88 and $5.01 \mathrm{ppm}$ assignable to $\mathrm{N}$-Me, olefinic proton $\mathrm{H}-10$ in cyanomethylene group (in annelated product 3a) and olefinic proton in the zwitterion $\mathbf{B}$ (Schemes 1,3) respectively, appeared. During the next three days the intensities of these signals gradually increased and singlets at 1.29 and $1.38 \mathrm{ppm}$ become observable. After 11 days, signals for the annelated adduct 3a were considerably augmented and weak signals at 3.16 and $4.38 \mathrm{ppm}$ emerged attributable to $\mathrm{N}$-Me and olefinic proton in the intermediate $\mathbf{C}$ (Schemes 2, 3). After 20 days, the intensities of these signals rose with a simultaneous decrease of the intensity of the olefinic proton signal in the zwitterion $\mathbf{B}(5.01 \mathrm{ppm})$. Finally, after 35 days, the singlet at $5.01 \mathrm{ppm}$ disappeared and the signal intensities of annelated adduct 3a $(1.29,1.38,2.96$ and $4.88 \mathrm{ppm})$ fell sharply. In this spectrum, the signals of intermediates $\mathbf{C}(3.16$ and $4.38 \mathrm{ppm})$ and $\mathbf{D}(4.35 \mathrm{ppm})$ dominated. When the reaction mixture was passed through the column packed with alumina (chloroform/benzene/ethanol, 20:4:1, mixture as eluent), the final rearrangement products 5a was isolated (Scheme 2).

Thus, the monitoring confirms Schemes 1 and 2, though under the conditions employed, the combined rearrangement annelation sequence proceeds only slowly and did not reach completion, so that even after 35 days the reaction mixture consisted of intermediates $\mathbf{C}$ and $\mathbf{D}$.

\section{Conclusions}

In conclusion, a novel one-pot efficient methodology for the stereoselective synthesis of previously unknown imidazo[4,5- $b$ ]pyridine derived tricyclic fused functionalized systems $-(Z)$ - 
1,3-oxazolo[3,2-a]imidazo[4,5-b]pyridines, has been developed (yields up to 88\%). The methodology represents an exceptionally facile $\left(20-50{ }^{\circ} \mathrm{C}\right)$ metal-free stereoselective (relative to the cyanomethylene function) annelation of imidazo[4,5-b]pyridines with cyanoacetylenic tertiary $\alpha$-alcohols, involving intermediate zwitterions. The 1,3-oxazolo[3,2-a]imidazo[4,5$b$ ]pyridines, when passed through alumina, or in aqueous solvents at room temperature, undergo an easy hydrolytic multi-step domino rearrangement to functionalized derivatives of 2,3diaminopyridines - $(E)$-pyridinyl- $N$-alkylformamides, in excellent to quantitative yields. The principal steps of the rearrangement were verified by NMR monitoring to show that initially the cleavage of the $\mathrm{C}(2)-\mathrm{O}$ bond of the oxazole cycle by the molecule of water occurs. Then follows the rearrangement of the semi-aminal moiety forking the formamide function and a sequence of 1,3-prototropic shifts and the iminodihydrofuran ring closure. A straightforward threecomponent access to derivatives of 2,3-diaminopyridines conjugated with 2-aminodihydrofurans directly from imidazo[4,5- $b$ ]pyridine, cyanoacetylenic tertiary $\alpha$-alcohols and water has been elaborated. The results contribute to the fundamental chemistry of imidazole, pyridine and acetylenes as well as to the development of novel imidazo[4,5-b]pyridines.

\section{Experimental Section}

General. NMR spectra were run on a Bruker DPX-400 spectrometer with HMDS as an internal standard. UV-VIS spectra were measured on a Perkin-Elmer Lambda 35 spectrometer at room temperature $(\mathrm{EtOH}, \mathrm{d}=0.1 \mathrm{~cm})$. IR spectra were recorded on a IFS 25 instrument. Column and thin-layer chromatography was carried out on neutral $\mathrm{Al}_{2} \mathrm{O}_{3}$ with chloroform/benzene/ethanol (20:4:1) mixture as eluent (length of column $=35 \mathrm{~cm}, \varnothing=0.8 \mathrm{~cm}$ ). The reaction was monitored by the disappearance of absorption bands of initial acetylenes $\mathbf{2 a}, \mathbf{b}$ in the reaction mixture (IR spectroscopy). Alkylation of imidazo[4,5-b]pyridines 1a,b was carried out according to the procedures: ${ }^{19} \mathrm{mp} \mathbf{1 a} 56{ }^{\circ} \mathrm{C}$ (hexane) $\left[\mathrm{mp} 76-78{ }^{\circ} \mathrm{C}^{20}\right.$; mp 1b $79-81{ }^{\circ} \mathrm{C}$ (hexane) $\left[\mathrm{mp} 83{ }^{\circ} \mathrm{C}^{21}\right]$; mp 1c $134-135{ }^{\circ} \mathrm{C}$ (acetone) [mp $119{ }^{\circ} \mathrm{C}^{21}$ ]. Cyanoacetylenic tertiary $\alpha$-alcohols $\mathbf{2 a}, \mathbf{b}$ were prepared by the method. ${ }^{11}$ Labeling of hydrogen and carbon atoms in compounds 3a-e and 5a-e are given in Figure 4.

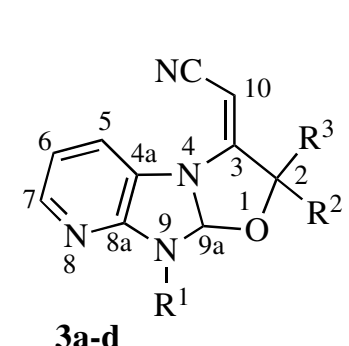

3a-d
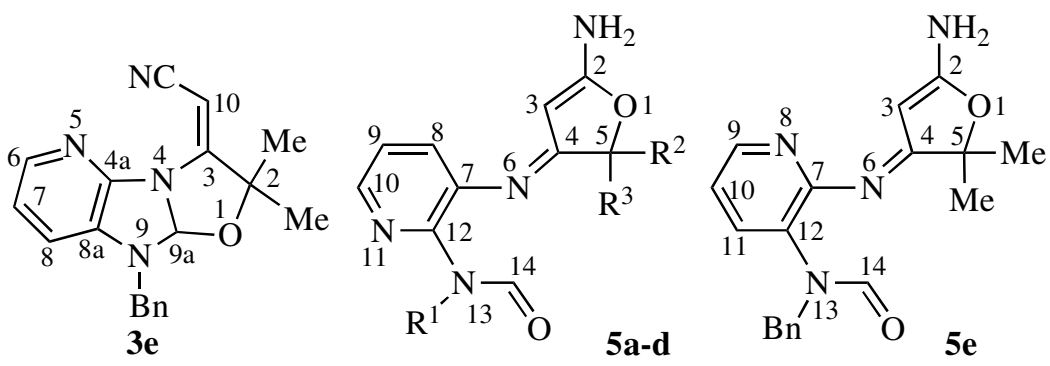

Figure 4. Labeling of hydrogen and carbon atoms in compounds 3a-e and 5a-e. 
X-ray diffraction. The X-ray diffraction study of compound $\mathbf{5 c}$ was carried out on an EnrafNonius CAD-4 diffractometer at room temperature $\left(\omega / 2 \theta\right.$-scans, Mo- $\mathrm{K}_{\alpha}$ radiation, graphite monochromator). The crystal structure was solved by direct methods followed by Fouriersyntheses using SHELXS-97 programs. ${ }^{22}$ The structure refined by a full matrix least-squares anisotropic procedure using SHELXTL-97 programs. ${ }^{23}$ The parameters of hydrogen atoms were defined experimentally and refined anisotropically, except for parameters of hydrogen of the methyl group which were calculated geometrically. These data are available via www.ccdc.cam.uk/contsretrieving.html (or from CCDC, 12 Union Cambrige CB2 1EZ, UK, fax: +44 (0) 1223336 033; or e-mail: deposit@ccdc.cam.ac.uk). Any request to the CCDC for data should quote the full literature citation and CCDC reference number CCDC 826322 (for 5c).

\section{General synthetic procedure for the preparation of products 3, exemplified by} (Z)-3-cyanomethylene-2,3,9,9a-tetrahydro-9-methyl-2,2-dimethyl-1,3-oxazolo[3,2-a]imidazo[4,5-b]pyridine (3a)

A mixture of 3-methyl-3H-imidazo[4,5-b]pyridine (1a) $(0.133 \mathrm{~g}, 1 \mathrm{mmol})$ and cyanoacetylenic alcohol 2a $(0.109 \mathrm{~g}, 1 \mathrm{mmol})$ in dry $\mathrm{MeCN}(0.2 \mathrm{~mL})$ was stirred at $45-50{ }^{\circ} \mathrm{C}$ for $30 \mathrm{~h}$. The solvent was removed and the residue was washed with anhydrous $\mathrm{Et}_{2} \mathrm{O}(5 \times 0.3 \mathrm{~mL})$ to give 1,3 oxazoloimidazopyridine 3a, yield 88\%, $0.212 \mathrm{~g}$, light-pink powder, mp $98-101{ }^{\circ} \mathrm{C}$; IR $\left(v_{\max }, \mathrm{cm}^{-}\right.$ $\left.{ }^{1}\right):$ 1060, 1081, 1123 (C-O-C), 1652 (C=C), 2202 (=CH-CN), 3024 (=CH-CN). ${ }^{1} \mathrm{H}$ NMR (400.13 $\left.\mathrm{MHz}, \mathrm{CDCl}_{3}\right): \delta_{\mathrm{H}} 1.29,1.38\left(6 \mathrm{H}, 2 \times \mathrm{s}, 2 \times \mathrm{CH}_{3}\right), 2.96\left(3 \mathrm{H}, \mathrm{s}, \mathrm{NCH}_{3}\right), 4.43(1 \mathrm{H}, \mathrm{s}, \mathrm{H}-10), 6.28$ $(1 \mathrm{H}, \mathrm{s}, \mathrm{H}-9 \mathrm{a}), 6.48(1 \mathrm{H}, \mathrm{dd}, \mathrm{H}-6), 7.63\left(1 \mathrm{H}, \mathrm{d},{ }^{3} J_{\mathrm{H} 6, \mathrm{H} 7}=5.2 \mathrm{~Hz}, \mathrm{H}-7\right), 7.68\left(1 \mathrm{H}, \mathrm{d},{ }^{3} J_{\mathrm{H} 5, \mathrm{H} 6}=7.7\right.$ $\mathrm{Hz}, \mathrm{H}-5) .{ }^{13} \mathrm{C}$ NMR $\left(100.62 \mathrm{MHz}, \mathrm{CDCl}_{3}\right): \delta_{\mathrm{C}} 26.5,28.0\left(2 \times \mathrm{CH}_{3}\right), 29.1\left(\mathrm{NCH}_{3}\right), 70.0(\mathrm{C}-10)$, 83.6 (C-2), 105.4 (C-9a), 113.8 (C-6), 118.6 (CN), 120.7 (C-5), 128.9 (C-4a), 142.3 (C-7), 153.8 (C-8a), 167.9 (C-3); Anal. Calcd for $\mathrm{C}_{13} \mathrm{H}_{14} \mathrm{~N}_{4} \mathrm{O}$ (242.20): C, 64.45; H, 5.82; N, 23.12\%. Found: C, 64.60; H, 5.89; N, 23.10\%.

(Z)-3-Cyanomethylene-2,3,9,9a-tetrahydro-9-benzyl-2,2-dimethyl-1,3-oxazolo[3,2-a]imidazo[4,5-b]pyridine (3b). Light-yellow powder, yield 70\%, $0.256 \mathrm{~g}, \mathrm{mp} 102-104{ }^{\circ} \mathrm{C}$; IR $\left(v_{\max }\right.$, $\left.\mathrm{cm}^{-1}\right)$ : 1108, 1136, $1156(\mathrm{C}-\mathrm{O}-\mathrm{C}), 1650(\mathrm{C}=\mathrm{C}), 2213(=\mathrm{CH}-\mathrm{CN}), 3066(=\mathrm{CH}-\mathrm{CN}) .{ }^{1} \mathrm{H}$ NMR $\left(400.13 \mathrm{MHz}, \mathrm{CDCl}_{3}\right): \delta_{\mathrm{H}} 1.39,1.43\left(6 \mathrm{H}, 2 \times \mathrm{s}, 2 \times \mathrm{CH}_{3}\right), 4.53,4.97\left(2 \mathrm{H}, 2 \times \mathrm{d},{ }^{2} J_{\mathrm{H}, \mathrm{H}}=15.6 \mathrm{~Hz}\right.$, $\mathrm{CH}_{2}$ from $N$-benzyl), 4.54 (1H, s, H-10), 6.39 (1H, s, H-9a), 6.65 (1H, dd, H-6), 7.24-7.30 (5H, m, Ph from $N$-benzyl), $7.78\left(1 \mathrm{H}, \mathrm{d},{ }^{3} J_{\mathrm{H} 6, \mathrm{H} 7}=5.4 \mathrm{~Hz}, \mathrm{H}-7\right), 7.84\left(1 \mathrm{H}, \mathrm{d},{ }^{3} J_{\mathrm{H} 5, \mathrm{H} 6}=7.7 \mathrm{~Hz}, \mathrm{H}-5\right)$. ${ }^{13} \mathrm{C}$ NMR $\left(100.62 \mathrm{MHz}, \mathrm{CDCl}_{3}\right): \delta_{\mathrm{C}} 26.5,28.1\left(2 \times \mathrm{CH}_{3}\right), 43.1\left(\mathrm{CH}_{2}\right.$ from $N$-benzyl), $70.7(\mathrm{C}-$ 10), 83.3 (C-2), 103.4 (C-9a), 114.2 (C-6), 118.6 (CN), 120.8 (C-5), 127.7, 128.1, 128.7 (m,o,pC, Ph from $N$-benzyl), 128.9 (C-4a), 136.4 (i-C, Ph from $N$-benzyl), 142.4 (C-7), 153.2 (C-8a), 168.2 (C-3); Anal. Calcd for $\mathrm{C}_{19} \mathrm{H}_{18} \mathrm{~N}_{4} \mathrm{O}$ (318.38): C, 71.68; H, 5.70; N, 17.60\%. Found: C, $71.95 ; \mathrm{H}, 5.42 ; \mathrm{N}, 17.85 \%$.

(Z)-Spiro-1,3-oxazolo[3,2-a]imidazo[4,5-b]pyridine (3c). Red powder, yield 75\%, $0.212 \mathrm{~g}, \mathrm{mp}$ 103-105 ${ }^{\circ} \mathrm{C}$; IR ( $\left.v_{\max }, \mathrm{cm}^{-1}\right)$ : 1052, 1074, 1125, 1148, 1167 (C-O-C), $1644(\mathrm{C}=\mathrm{C}), 2206$ (=CH$C N), 3077(=C H-C N) .{ }^{1} \mathrm{H}$ NMR $\left(400.13 \mathrm{MHz}, \mathrm{CDCl}_{3}\right): \delta_{\mathrm{H}} 1.10-1.90(10 \mathrm{H}, \mathrm{m}$, cyclohexyl), 3.14 $\left(3 \mathrm{H}, \mathrm{s}, \mathrm{NCH}_{3}\right), 4.55(1 \mathrm{H}, \mathrm{s}, \mathrm{H}-10), 6.42(1 \mathrm{H}, \mathrm{s}, \mathrm{H}-9 \mathrm{a}), 6.63(1 \mathrm{H}, \mathrm{dd}, \mathrm{H}-6), 7.78\left(1 \mathrm{H}, \mathrm{d},{ }^{3} \mathrm{~J}_{\mathrm{H} 6, \mathrm{H} 7}=\right.$ 
$5.4 \mathrm{~Hz}, \mathrm{H}-7), 7.83\left(1 \mathrm{H}, \mathrm{d},{ }^{3} J_{\mathrm{H} 5, \mathrm{H} 6}=7.8 \mathrm{~Hz}, \mathrm{H}-5\right) .{ }^{13} \mathrm{C} \mathrm{NMR}\left(100.62 \mathrm{MHz}, \mathrm{CDCl}_{3}\right): \delta_{\mathrm{C}} 21.3-36.2$ $\left(5 \times \mathrm{CH}_{2}\right.$, cyclohexyl), $28.6\left(\mathrm{NCH}_{3}\right), 70.3(\mathrm{C}-10), 84.9$ (C-2), 105.2 (C-9a), $113.3(\mathrm{C}-6), 118.2$ (CN), 120.3 (C-5), 128.7 (C-4a), 141.8 (C-7), 153.4 (C-8a), 167.6 (C-3); Anal. Calcd for $\mathrm{C}_{16} \mathrm{H}_{18} \mathrm{~N}_{4} \mathrm{O}$ (282.34): C, 68.06; H, 6.43; N, 19.84\%. Found: C, 68.33; H, 6.56; N, $19.55 \%$.

(Z)-Spiro-1,3-oxazolo[3,2-a]imidazo[4,5-b]pyridine (3d). Light-yellow powder, yield 50\%, $0.197 \mathrm{~g}, \mathrm{mp} 108-110{ }^{\circ} \mathrm{C}$; IR $\left(v_{\max }, \mathrm{cm}^{-1}\right): 1064,1082,1105,1130,1159,1174$ (C-O-C), 1647 $(\mathrm{C}=\mathrm{C}), 2209(=\mathrm{CH}-\mathrm{CN}), 3066(=\mathrm{CH}-\mathrm{CN}) .{ }^{1} \mathrm{H} \mathrm{NMR}\left(400.13 \mathrm{MHz}, \mathrm{CDCl}_{3}\right): \delta_{\mathrm{H}} 1.10-1.90(10 \mathrm{H}$, m, cyclohexyl), $4.57(1 \mathrm{H}, \mathrm{s}, \mathrm{H}-10), 4.67,4.92\left(2 \mathrm{H}, 2 \times \mathrm{d},{ }^{2} J_{\mathrm{H}, \mathrm{H}}=15.5 \mathrm{~Hz}, \mathrm{CH}_{2}\right.$ from $N$-benzyl), $6.41(1 \mathrm{H}, \mathrm{s}, \mathrm{H}-9 \mathrm{a}), 6.65(1 \mathrm{H}, \mathrm{dd}, \mathrm{H}-6), 7.25-7.40(5 \mathrm{H}, \mathrm{m}, \mathrm{Ph}$ from $N$-benzyl $), 7.80\left(1 \mathrm{H}, \mathrm{d},{ }^{3} J_{\mathrm{H} 6, \mathrm{H} 7}\right.$ $=5.5 \mathrm{~Hz}, \mathrm{H}-7), 7.82\left(1 \mathrm{H}, \mathrm{d},{ }^{3} J_{\mathrm{H} 5, \mathrm{H} 6}=7.8 \mathrm{~Hz}, \mathrm{H}-5\right) .{ }^{13} \mathrm{C} \mathrm{NMR}\left(100.62 \mathrm{MHz}, \mathrm{CDCl}_{3}\right): \delta_{\mathrm{C}} 21.6-$ $24.7\left(5 \times \mathrm{CH}_{2}\right.$, cyclohexyl), $46.2\left(\mathrm{CH}_{2}\right.$ from $N$-benzyl), 71.5 (C-10), 84.9 (C-2), 103.7 (C-9a), 114.0 (C-6), $118.5(\mathrm{CN}), 120.6$ (C-5), 127.2, 128.2, 128.5 (m,o,p-C, Ph from $N$-benzyl), 129.2 (C-4a), 136.4 (i-C, Ph from $N$-benzyl), 142.2 (C-7), 153.1 (C-8a), 168.4 (C-3); Anal. Calcd for $\mathrm{C}_{22} \mathrm{H}_{22} \mathrm{~N}_{4} \mathrm{O}$ (358.44): C, 73.72; H, 6.19; N, 15.63\%. Found: C, 73.45; H, 5.99; N, 15.37\%.

(Z)-2-[9-Benzyl-2,2-dimethyl-9,9a-dihydro[1,3]oxazolo[2',3':2,3]imidazo[4,5-b]pyridin-

3(2H)-yliden]acetonitrile (3e). Light-brown powder, yield $18 \%, 0.057 \mathrm{~g}, \mathrm{mp} \mathrm{121-124}{ }^{\circ} \mathrm{C}$; IR $\left(v_{\max }, \mathrm{cm}^{-1}\right): 1079,1155(\mathrm{C}-\mathrm{O}-\mathrm{C}), 1634(\mathrm{C}=\mathrm{C}), 2204(=\mathrm{CH}-\mathrm{CN}), 3063(=\mathrm{CH}-\mathrm{CN}) .{ }^{1} \mathrm{H}$ NMR $\left(400.13 \mathrm{MHz}, \mathrm{CDCl}_{3}\right): \delta_{\mathrm{H}} 1.39,1.45\left(6 \mathrm{H}, 2 \times \mathrm{s}, 2 \times \mathrm{CH}_{3}\right), 4.15,4.55\left(2 \mathrm{H}, 2 \times \mathrm{d},{ }^{2} J_{\mathrm{H}, \mathrm{H}}=15.5 \mathrm{~Hz}\right.$, $\mathrm{CH}_{2}$ from $N$-benzyl), 4.51 (1H, s, H-10), $6.44(1 \mathrm{H}, \mathrm{s}, \mathrm{H}-9 \mathrm{a}), 6.73(1 \mathrm{H}, \mathrm{dd}, \mathrm{H}-7), 7.20-7.50(5 \mathrm{H}$, m, Ph from $N$-benzyl), $7.55\left(1 \mathrm{H}, \mathrm{d},{ }^{3} J_{\mathrm{H} 7, \mathrm{H} 8}=7.7 \mathrm{~Hz}, \mathrm{H}-8\right), 7.75\left(1 \mathrm{H}, \mathrm{d},{ }^{3} J_{\mathrm{H} 6, \mathrm{H} 7}=5.5 \mathrm{~Hz}, \mathrm{H}-6\right)$. ${ }^{13} \mathrm{C} \mathrm{NMR}\left(100.62 \mathrm{MHz}, \mathrm{CDCl}_{3}\right): \delta_{\mathrm{C}} 25.5,27.5\left(2 \times \mathrm{CH}_{3}\right), 44.1\left(\mathrm{CH}_{2}\right.$ from $N$-benzyl), $62.7(\mathrm{C}$ 10), 79.4 (C-2), 101.0 (C-9a), 114.0 (C-7), 118.5 (CN), 123.0 (C-8), 126.6, 127.9, 128.6 (m,o,pC, Ph from $N$-benzyl), 130.2 (C-8a), 141.1 (i-C, Ph from $N$-benzyl), 142.1 (C-6), 145.1 (C-4a), 160.5 (C-3); Anal. Calcd for $\mathrm{C}_{19} \mathrm{H}_{18} \mathrm{~N}_{4} \mathrm{O}$ (318.38): C, 71.86; H, 5.70; N, 17.60\%. Found: C, $71.89 ; \mathrm{H}, 5.52 ; \mathrm{N}, 17.68 \%$.

General synthetic procedure for the preparation of products 5, exemplifided by $(E)-N-(3-$ \{[5-amino-2,2-dimethyl-3(2H)-furanyliden]amino\}-2-pyridinyl)- $N$-methylformamide (5a)

1,3-Oxazoloimidazopyridine 3a $(0.145 \mathrm{~g}, 0.6 \mathrm{mmol})$ was dissolved in a mixture of $\mathrm{CHCl}_{3}$ benzene-EtOH (20:4:1, $5 \mathrm{~mL})$. Column chromatography on $\mathrm{Al}_{2} \mathrm{O}_{3}$ was employed to afford formamide 5a, yield $83 \%, 0.130 \mathrm{~g}$, light-yellow powder, $\mathrm{mp} 183-184{ }^{\circ} \mathrm{C}$; IR $\left(v_{\max }, \mathrm{cm}^{-1}\right): 1066$, 1097, 1122, 1135 (C-O-C), 1676 (C=O), 3294, $3361\left(\mathrm{NH}_{2}\right) .{ }^{1} \mathrm{H}$ NMR (400.13 MHz, DMSO-d $)$ : $\delta_{\mathrm{H}} 1.40\left(6 \mathrm{H}, \mathrm{s}, 2 \times \mathrm{CH}_{3}\right), 3.13\left(3 \mathrm{H}, \mathrm{s}, \mathrm{NCH}_{3}\right), 4.31(1 \mathrm{H}, \mathrm{s}, \mathrm{H}-3), 7.18(1 \mathrm{H}, \mathrm{dd}, \mathrm{H}-9), 7.32(1 \mathrm{H}, \mathrm{d}$, $\left.{ }^{3} J_{\mathrm{H} 8, \mathrm{H} 9}=7.7 \mathrm{~Hz}, \mathrm{H}-8\right), 7.50\left(2 \mathrm{H}, \mathrm{s}, \mathrm{NH}_{2}\right), 8.01\left(1 \mathrm{H}, \mathrm{d},{ }^{3} J_{\mathrm{H} 9, \mathrm{H} 10}=4.6 \mathrm{~Hz}, \mathrm{H}-10\right), 8.26(1 \mathrm{H}, \mathrm{s}, \mathrm{H}-$ 14). ${ }^{13} \mathrm{C}$ NMR $\left(100.62 \mathrm{MHz}, \mathrm{DMSO}-d_{6}\right): \delta_{\mathrm{C}} 25.3\left(2 \times \mathrm{CH}_{3}\right), 30.2\left(\mathrm{NCH}_{3}\right), 69.6(\mathrm{C}-3), 89.0(\mathrm{C}-$ 5), 122.1 (C-9), 130.7 (C-8), 141.0 (C-10), 142.8 (C-2), 147.1 (C-7), 163.2 (C-14), 173.9 (C-2), $178.1(\mathrm{C}-4)$. UV/Vis $(\mathrm{EtOH}): \lambda_{\max }(\log \varepsilon)=298(4.42) \mathrm{nm}$; Anal. Calcd for $\mathrm{C}_{13} \mathrm{H}_{16} \mathrm{~N}_{4} \mathrm{O}_{2}(260.30)$ : C, 59.99; H, 6.20; N, 21.52\%. Found: C, 59.69; H, 6.47; N, 21.48\%.

(E)- $\boldsymbol{N}$-(3-\{[5-Amino-2,2-dimethyl-3(2H)-furanyliden]amino\}-2-pyridinyl)- $\boldsymbol{N}$-benzyl-

formamide (5b). White powder, yield 98\%, $0.206 \mathrm{~g}, \mathrm{mp} 160-161{ }^{\circ} \mathrm{C}$; IR $\left(v_{\max }, \mathrm{cm}^{-1}\right): 1076,1106$ 
(C-O-C), $1676(\mathrm{C}=\mathrm{O}), 3331,3356\left(\mathrm{NH}_{2}\right) .{ }^{1} \mathrm{H}$ NMR (400.13 MHz, DMSO- $\left.d_{6}\right): \delta_{\mathrm{H}} 1.45(6 \mathrm{H}, \mathrm{s}, 2$ $\left.\times \mathrm{CH}_{3}\right), 4.41(1 \mathrm{H}, \mathrm{s}, \mathrm{H}-3), 5.09\left(2 \mathrm{H}, \mathrm{s}, \mathrm{CH}_{2}\right.$ from $N$-benzyl), $7.14(1 \mathrm{H}, \mathrm{dd}, \mathrm{H}-9), 7.14(1 \mathrm{H}, \mathrm{d}$, $\left.{ }^{3} J_{\mathrm{H} 8, \mathrm{H} 9}=7.6 \mathrm{~Hz}, \mathrm{H}-8\right), 7.20-7.35\left(5 \mathrm{H}, \mathrm{m}, \mathrm{Ph}\right.$ from $N$-benzyl), $7.57\left(2 \mathrm{H}, \mathrm{s}, \mathrm{NH}_{2}\right), 7.99(1 \mathrm{H}, \mathrm{d}$, $\left.{ }^{3} J_{\mathrm{H} 9, \mathrm{H} 10}=4.4 \mathrm{~Hz}, \mathrm{H}-10\right), 8.40(1 \mathrm{H}, \mathrm{s}, \mathrm{H}-14) .{ }^{13} \mathrm{C}$ NMR $\left(100.62 \mathrm{MHz}, \mathrm{DMSO}-d_{6}\right): \delta_{\mathrm{C}} 25.4(2 \times$ $\left.\mathrm{CH}_{3}\right), 45.5\left(\mathrm{CH}_{2}\right.$ from $N$-benzyl), 69.8 (C-3), 89.3 (C-5), 122.2 (C-9), 126.6, 126.9, 128.0 (m,o,p$\mathrm{C}, \mathrm{Ph}$ from $N$-benzyl), 130.3 (C-8), 137.9 (i-C, Ph from $N$-benzyl), 141.0 (C-10), 143.0 (C-12), 146.4 (C-7), 163.5 (C-14), 174.2 (C-2), 178.1 (C-4); Anal. Calcd for $\mathrm{C}_{19} \mathrm{H}_{20} \mathrm{~N}_{4} \mathrm{O}_{2}$ (336.39): C, $67.84 ; \mathrm{H}, 5.99 ; \mathrm{N}, 16.66 \%$. Found: C, 68.10; H, 5.87; N, 16.87\%.

(E)- $\boldsymbol{N}$-\{3-[(2-Amino-1-oxaspiro[4,5]dec-2-en-4-yliden)amino]-2-pyridinyl\}- $N$-methyl-

formamide (5c). Red powder, yield $91 \%, 0.272 \mathrm{~g}, \mathrm{mp} 219-221{ }^{\circ} \mathrm{C}$; IR $\left(v_{\max }, \mathrm{cm}^{-1}\right): 1072,1107$ (C-O-C), $1684(\mathrm{C}=\mathrm{O}), 3216,3352\left(\mathrm{NH}_{2}\right) .{ }^{1} \mathrm{H}$ NMR $\left(400.13 \mathrm{MHz}, \mathrm{DMSO}-d_{6}\right): \delta_{\mathrm{H}} 1.50-1.70$ $\left(10 \mathrm{H}, \mathrm{m}\right.$, cyclohexyl), $3.11\left(3 \mathrm{H}, \mathrm{s}, \mathrm{NCH}_{3}\right), 4.29(1 \mathrm{H}, \mathrm{s}, \mathrm{H}-3), 7.16(1 \mathrm{H}, \mathrm{dd}, \mathrm{H}-9), 7.28(1 \mathrm{H}, \mathrm{d}$, $\left.{ }^{3} J_{\mathrm{H} 8, \mathrm{H} 9}=7.8 \mathrm{~Hz}, \mathrm{H}-8\right), 7.48\left(2 \mathrm{H}, \mathrm{s}, \mathrm{NH}_{2}\right), 8.01\left(1 \mathrm{H}, \mathrm{d},{ }^{3} J_{\mathrm{H} 9, \mathrm{H} 10}=4.5 \mathrm{~Hz}, \mathrm{H}-10\right), 8.23(1 \mathrm{H}, \mathrm{s}, \mathrm{H}-$ 14). ${ }^{13} \mathrm{C}$ NMR (100.62 MHz, DMSO- $\left.d_{6}\right): \delta_{\mathrm{C}} 21.8-33.8\left(5 \times \mathrm{CH}_{2}\right.$, cyclohexyl), $30.4\left(\mathrm{NCH}_{3}\right), 70.3$ (C-3), 90.5 (C-5), 122.3 (C-9), 131.0 (C-8), 141.1 (C-10), 142.9 (C-12), 147.2 (C-7), 163.3 (C14), 174.3 (C-2), 178.2 (C-4); Anal. Calcd for $\mathrm{C}_{16} \mathrm{H}_{20} \mathrm{~N}_{4} \mathrm{O}_{2}$ (300.36): C, 63.98; H, 6.43; N, 18.65\%. Found: C, 63.68; H, 6.74; N, 18.36\%.

(E)- $N$-\{3-[(2-Amino-1-oxaspiro[4,5]dec-2-en-4-yliden)amino]-2-pyridinyl $\}-N$-benzyl-

formamide (5d). Similar to the synthesis of formamide $\mathbf{5 b}$, from 1,3-oxazolidinoimidazopyridine 3d $(0.093 \mathrm{~g}, 0.3 \mathrm{mmol})$ was prepared formamide $\mathbf{5 d}$, yield 93\%, $0.094 \mathrm{~g}$, lightbrown powder, mp 158-160 ${ }^{\circ} \mathrm{C}$; IR $\left(v_{\max }, \mathrm{cm}^{-1}\right): 1059,1112$ (C-O-C), 1659 (C=O), 3284, 3335 $\left(\mathrm{NH}_{2}\right) .{ }^{1} \mathrm{H}$ NMR $\left(400.13 \mathrm{MHz}, \mathrm{DMSO}-d_{6}\right): \delta_{\mathrm{H}} 1.55-1.80(10 \mathrm{H}, \mathrm{m}$, cyclohexyl), $4.39(1 \mathrm{H}, \mathrm{s}, \mathrm{H}-3)$, $5.06\left(2 \mathrm{H}, \mathrm{s}, \mathrm{CH}_{2}\right.$ from $N$-benzyl), $7.13(1 \mathrm{H}, \mathrm{d}, \mathrm{H}-8), 7.17\left(1 \mathrm{H}, \mathrm{dd},{ }^{3} J_{\mathrm{H} 8, \mathrm{H} 9}=7.6 \mathrm{~Hz}, \mathrm{H}-9\right), 7.30-$ $7.40(5 \mathrm{H}, \mathrm{m}, \mathrm{Ph}$ from $N$-benzyl $), 7.55\left(2 \mathrm{H}, \mathrm{s}, \mathrm{NH}_{2}\right), 7.98\left(1 \mathrm{H}, \mathrm{d},{ }^{3} J_{\mathrm{H} 9, \mathrm{H} 10}=4.4 \mathrm{~Hz}, \mathrm{H}-10\right), 8.37$ $(1 \mathrm{H}, \mathrm{s}, \mathrm{H}-14) .{ }^{13} \mathrm{C}$ NMR $\left(100.62 \mathrm{MHz}, \mathrm{DMSO}-d_{6}\right): \delta_{\mathrm{C}} 21.7-33.8\left(5 \times \mathrm{CH}_{2}\right.$, cyclohexyl), 45.6 $\left(\mathrm{CH}_{2}\right.$ from $N$-benzyl), 70.3 (C-3), 90.6 (C-5), 122.2 (C-9), 126.6, 126.9, 128.0 (m,o,p-C, $\mathrm{Ph}$ from $N$-benzyl), 130.4 (C-8), 137.8 (i-C, Ph from $N$ - benzyl), 140.9 (C-10, C-12), 146.3 (C-7), 163.4 (C-14), 174.4 (C-2), 178.1 (C-4); Anal. Calcd for $\mathrm{C}_{22} \mathrm{H}_{24} \mathrm{~N}_{4} \mathrm{O}_{2}$ (376.46): C, 70.19; H, 6.43; N, $14.88 \%$. Found: C, 69.99; H, 6.62; N, 14.56\%.

(E)- $\mathrm{N}$-(2-\{[5-Amino-2,2-dimethyl-3(2H)-furanyliden]amino\}-3-pyridinyl)- $N$-benzyl-

formamide (5e). Analogously, from 1-benzyl-1H-imidazo[4,5-b]pyridine 1c $(0.080 \mathrm{~g}, 0.25$ mmol) was prepared formamide 5e, yield 46\%, $0.039 \mathrm{~g}$, light-brown powder, mp 107-110 ${ }^{\circ} \mathrm{C}$; IR $\left(v_{\max }, \mathrm{cm}^{-1}\right):$ 1076, $1181(\mathrm{C}-\mathrm{O}-\mathrm{C}), 1664(\mathrm{C}=\mathrm{O}), 3283,3338\left(\mathrm{NH}_{2}\right) .{ }^{1} \mathrm{H}$ NMR $(400.13 \mathrm{MHz}$, DMSO- $\left.d_{6}\right): \delta_{\mathrm{H}} 1.37\left(6 \mathrm{H}, \mathrm{s}, 2 \times \mathrm{CH}_{3}\right), 4.59(1 \mathrm{H}, \mathrm{s}, \mathrm{H}-3), 5.39\left(2 \mathrm{H}, \mathrm{s}, \mathrm{CH}_{2}\right.$ from $N$-benzyl $), 6.54$ $(1 \mathrm{H}, \mathrm{dd}, \mathrm{H}-10), 7.03\left(1 \mathrm{H}, \mathrm{d},{ }^{3} J_{\mathrm{H} 10, \mathrm{H} 11}=7.2 \mathrm{~Hz}, \mathrm{H}-11\right), 7.30-7.40$ (5H, m, Ph from $N$-benzyl), 7.50 $\left(2 \mathrm{H}, \mathrm{s}, \mathrm{NH}_{2}\right), 7.68\left(1 \mathrm{H}, \mathrm{d},{ }^{3} \mathrm{~J}_{\mathrm{H} 9, \mathrm{H} 10}=5.9 \mathrm{~Hz}, \mathrm{H}-9\right), 8.78(1 \mathrm{H}, \mathrm{s}, \mathrm{H}-14) .{ }^{13} \mathrm{C} \mathrm{NMR}(100.62 \mathrm{MHz}$, DMSO- $\left.d_{6}\right): \delta_{\mathrm{C}} 25.0\left(2 \times \mathrm{CH}_{3}\right), 54.3\left(\mathrm{CH}_{2}\right.$ from $N$-benzyl), 70.4 (C-3), $89.4(\mathrm{C}-5), 110.4(\mathrm{C}-10)$, 126.2 (C-11), 127.5, 127.6, 128.5 ( $m, o, p-\mathrm{C}, \mathrm{Ph}$ from $N$-benzyl), 132.1 (C-9), 136.8 (i-C, Ph from $N$-benzyl), 143.8 (C-7), 154.5 (C-12), 169.8 (C-14), 174.0 (C-2, C-4); Anal. Calcd for $\mathrm{C}_{19} \mathrm{H}_{20} \mathrm{~N}_{4} \mathrm{O}_{2}$ (336.39): C, 67.84; H, 5.99; N, 16.66\%. Found: C, 68.08; H, 5.67; N, $16.56 \%$. 


\section{Acknowledgements}

This work was supported by Russian Fund for Basic Research (Grant No. 11-03-00203),

Presidium of RAS (Program 25) and Presidium of Department of Chemical Sciences and Materials RAS (Grant No. 5.1.3.).

\section{References}

1. General Organic Chemistry; Kochetkov, N. K. Ed.; Khimiya: Moscow, 1985; Vol. 8, 752 (In Russian) [Comprehensive Organic Chemistry; Barton, S. D.; Ollis, W. D.; Sammes, P. G. Eds; Pergamon Press: Oxford, 1979; Vol. 4].

2. (a) Kleemann, A.; Engel, J.; Kutscher, B.; Reichert, D. Pharmaceutical Substances: Syntheses, Patents, Applications; Thieme: Stuttgart-New York, 2001; 70, 2207. (b) Mashkovsky, M. D. Drugs; Divov, S. B. Ed.; Novaya Volna: Moscow, 2003; Vol. 1, 540; Vol. 2, 608 (In Russian).

3. (a) Lehner, M. D.; Marx, D.; Boer, R.; Strub, A.; Hesslinger, C.; Eltze, M.; Ulrich, W.-R.; Schwoebel, F.; Schermuly, R. T.; Barsig, J. J. Pharmacol. Exp. Ther. 2006, 317, 181. (b) Strub, A.; Ulrich, W.-R.; Hesslinger, C.; Eltze, M.; Fuch $\beta$, T.; Strassner, J.; Strand, S.; Lehner, M. D.; Boer, R. Mol. Pharmacol. 2006, 69, 328. (c) Tiso, M.; Strub, A.; Hesslinger, C.; Kenney, C. T.; Boer, R.; Stuehr, D. J. Mol. Pharmacol. 2008, 73, 1244.

4. Heerding, D. A.; Rhodes, N.; Leber, J. D.; Clark, T. J.; Keenan, R. M.; Lafrance, L. V.; Li, M.; Safonov, I. G.; Takata, D. T.; Venslavsky, J. W.; Yamashita, D. S.; Choudhry, A. E.; Copeland, R. A.; Lai, Z.; Schaber, M. D.; Tummino, P. J.; Strum, S. L.; Wood, E. R.; Duckett, D. R.; Eberwein, D.; Knick, V. B.; Lansing, T. J.; McConnel, R. T.; Zhang, S. Y.; Minthorn, E. A.; Concha, N. O.; Warren, G. L.; Kumar, R. J. Med. Chem. 2008, 51, 5663.

5. Kyochiro, I.; Nobumasa, O.; Takeshi, K.; Hitoshi, A.; Akihiro, W.; Mayumi, S.; Naoko, H.; Haruhiko, M.; Hidenori, T.; Jun, S. Eur. Pat. Appl. 2006, (JP). EP 1724271 A1, 05719958.0, PCT/JP2005/003656. 22.11.2006, Bulletin 2006, 47.

6. (a) Bukowski, L. Chem. Heterocycl. Compd. 2002, 38, 828. (b) Bukowski, L.; Zwolska, Z.; Augustynowicz-Kopec, E. Chem. Heterocycl. Compd. 2006, 42, 1358.

7. Oguchi, M.; Wada, K.; Honma, H.; Tanaka, A.; Kaneko, T.; Sakakibara, S.; Ohsumi, J.; Serizawa, N.; Fujiwara, T.; Horikoshi, H.; Fujita, T. J. Med. Chem. 2000, 43, 3052.

8. (a) Chakravarty, P. K.; Naylor, E. M.; Chen, A.; Chang, R. S. L.; Chen, T.-B.; Faust, K. A.; Lotti, V. J.; Kivlighn, S. D.; Gable, R. A.; Zingaro, G. J.; Schorn, T. W.; Schaffer, L. W.; Broten, T. P.; Siegl, P. K. S.; Patchett, A. A.; Greenlee, W. J. J. Med. Chem. 1994, 37, 4068. (b) Cappelli, A.; Mohr, G. P.; Giuliani, G.; Galeazzi, S.; Anzini, M.; Mennuni, L.; Ferrari, F.; Makovec, F.; Kleinrath, E. M.; Langer, T.; Valoti, M.; Giorgi, G.; Vomero, S. J. Med. Chem. 2006, 49, 6451. 
9. Scribner, A.; Dennis, R.; Hong, J.; Lee, S.; McIntyre, D.; Perrey, D.; Feng, D.; Fisher, M.; Wyvratt, M.; Leavitt, P.; Liberator, P.; Gurnett, A.; Brown, C.; Mathew, J.; Thompson, D.; Schmatz, D.; Biftu, T. Eur. J. Med. Chem. 2007, 42, 1334.

10. Ishida, Y.; Ohta, K.; Iton, S.; Nakahama, T.; Miki, H.; Yoshikawa, H. J. Pesticide Sci. 1993, $18,175$.

11. (a) Landor, S. R.; Demetriou, B.; Grzeskowiak, R.; Pavey, D. J. Organomet. Chem. 1975, 93, 129. (b) Trofimov, B. A.; Andriyankova, L. V.; Shaikhudinova, S. I.; Kazantseva, T. I.; Mal'kina, A. G.; Afonin, A. V. Synthesis 2002, 853.

12. Trofimov, B. A.; Andriyankova, L. V.; Zhivet'ev, S. A.; Mal'kina, A. G.; Voronov, V. K. Tetrahedron Lett. 2002, 43, 1093.

13. Andriyankova, L. V.; Mal'kina, A. G.; Afonin, A. V.; Trofimov, B. A. Mendeleev Commun. 2003, 186.

14. Andriyankova, L. V.; Mal'kina, A. G.; Nikitina, L. P.; Belyaeva, K. V.; Ushakov, I. A.; Afonin, A. V.; Nikitin, M. V.; Trofimov, B. A. Tetrahedron 2005, 61, 8031.

15. Trofimov, B. A.; Andriyankova, L. V.; Tlegenov, R. T.; Mal'kina, A. G.; Afonin, A. V.; Il'icheva, L. N.; Nikitina, L. P. Mendeleev Commun. 2005, 33.

16. (a) Trofimov, B. A.; Andriyankova, L. V.; Mal'kina, A. G.; Belyaeva, K. V.; Nikitina, L. P.; Dyachenko, O. A.; Kazheva, O. N.; Chekhlov, A. N.; Shilov, G. V.; Afonin, A. V.; Ushakov, I. A.; Baikalova, L. V. Eur. J. Org. Chem. 2007, 1018. (b) Andriyankova, L. V.; Belyaeva, K. V.; Nikitina, L. P.; Mal'kina, A. G.; Afonin, A. V.; Trofimov, B. A. Synthesis 2010, 2828.

17. (a) Miller, S. I.; Tanaka, R. In Selective Organic Transformation; Thyagarajan, B. S. Ed.; Wiley-Interscience: New York, 1970; Vol. 1, 143. (b) Dickstein, J. I.; Miller, S. I. In The Chemistry of the Carbon-Carbon Triple Bond; Patai, S. Ed.; Wiley: New York, 1978; Vol. 2, 814.

18. Bondi, A. J. Phys. Chem. 1964, 68, 441.

19. Starikova, O. V.; Dolgushin, G. V.; Larina, L. I.; Komarova, T. N.; Lopyrev, V. A. Arkivoc 2003, xiii, 119.

20. Mizuno, Y.; Ikehara, M.; Iton, T.; Saito, K. J. Org. Chem. 1963, 28, 1837.

21. Khanna, I. K.; Weier, R. M.; Lentz, K. T.; Swenton, L.; Lankin, D. C. J. Org. Chem. 1995, $60,960$.

22. Sheldrick, G. M. SHELXS-97: Program for crystal structure determination; University of Göttingen: Göttingen, Germany, 1997.

23. Sheldrick, G. M. SHELXL-97: Program for the refinement of crystal structures; University of Göttingen: Göttingen, Germany, 1997. 